\title{
Coarse particulate organic matter in the interstitial zone of three French headwater streams
}

\author{
Julien Cornut ${ }^{1,2 *}$, Arnaud Elger ${ }^{1,2}$, Axel Greugny ${ }^{1,2}$, Maelys Bonnet ${ }^{1,2}$ and Eric Chauvet ${ }^{1,2}$ \\ ${ }^{1}$ Université de Toulouse; INP, UPS; EcoLab (Laboratoire Ecologie Fonctionnelle et Environnement), 118 Route de Narbonne, \\ 31062 Toulouse, France \\ 2 CNRS, EcoLab, 31062 Toulouse, France
}

Received 16 September 2011; Accepted 8 May 2012

\begin{abstract}
Headwater woodland streams are primarily heterotrophic: they receive substantial inputs of organic matter from the riparian vegetation, while autochthonous primary production is generally low. A substantial part of leaf litter entering running waters may be buried in the streambed because of flooding and sediment movement. Although the general significance of the hyporheic zone for stream metabolism has been reported early, organic matter storage within the sediment of streams has received less attention, with most studies only quantifying accumulations at the streambed surface and ignoring other stream compartments. In the present study, the amounts of three fractions of coarse particulate organic matter (CPOM; $>16,4-16$ and 1-4 mm) were determined in late autumn and early spring in the interstitial and benthic zones of three headwater streams of the Montagne Noire (South-Western France) differing in their substratum grain size. Our findings demonstrated that the total CPOM content in the interstitial zone can be much (up to one order of magnitude) higher than at the sediment surface. The sandy bottomed stream exhibited a higher amount of CPOM (whatever the size fraction) than the two other streams, suggesting that the sediment particle size may be a major determinant of CPOM storage. Given the large amount of organic matter stored in the interstitial zone, this compartment may play an important role for the carbon turnover and associated trophic dynamics in the stream ecosystem.
\end{abstract}

Key words: Organic matter / hyporheic zone / river sediment / headwater stream / litter breakdown

\section{Introduction}

Low-order forested streams, where light limitation restricts primary production, rely upon the input of organic matter from the riparian zone to fuel in-stream processes (Vannote et al., 1980). Thus, benthic coarse particulate organic matter (CPOM; e.g. leaves, wood and twigs) is a pivotal component of the functioning of these streams. It often forms the basis of the trophic structure of streams, being the major source of organic matter and energy in woodland stream ecosystems (Cummins et al., 1989). The decomposition of this organic matter is a key ecosystem-level process integrating the activities of both microbial and invertebrate decomposers (Gessner and Chauvet, 1994; Suberkropp, 1998; Graça, 2001; Hieber and Gessner, 2002). The accumulations of litter also

\footnotetext{
*Corresponding author: J. Cornut, Leibniz Institute of Freshwater Ecology and Inland Fisheries, Alte Fischerhütte 2, D-16775 Stechlin-Neuglobsow, Germany. E-mail: cornut@igb-berlin.de
}

provide physical structures, affecting geomorphology (Keller and Swanson, 1979) and serving as a habitat for organisms (Malmqvist et al., 1978; Short and Ward, 1981).

During the last four decades, studies on the dynamics of organic matter in streams have mostly been limited to benthic habitats, i.e., with processes occurring above the streambed surfaces (Kaushik and Hynes, 1971; Webster and Benfield, 1986; Jones, 1997). In parallel, the general significance of a second compartment, the hyporheic zone, was reported (Orghidan, 1959; Schwoerbel, 1961, 1964; Williams and Hynes, 1974; Triska et al., 1989; Gibert et al., 1990; Vervier et al., 1992; White, 1993) and the major contribution of the hyporheic zone to stream metabolism was also reported by Grimm and Fisher (1984). In the same time, authors such as Webster (1975), Webster and Patten (1979) and Newbold et al. (1981, 1982) introduced the concepts of nutrient and carbon spiralling describing the simultaneous processes of downstream movement with patterns of immobilization and mineralization. This spiralling concept, stressing that streams are prime sites of matter retention and processing, 
strongly contrasted with the reductionist view of other researchers as reported by Boulton (2000), considering these lotic ecosystems only as "pipes" conducting water, solutes and organic matter from the catchment downstream. Organic matter storage within stream sediments has received less attention than at the surface of sediments. However large standing stocks of particulate organic matter (POM) may occasionally be buried in sediments and significantly contribute to hyporheic metabolism (Metzler and Smock, 1990; Sobczak et al., 1998), and therefore to the overall ecological functioning of headwater streams.

Relatively little work has attempted to quantify POM buried in the sediments of headwater streams as usually it occurs following spates or other depositional events (but see Leichtfried, 1985, 1988; Metzler and Smock, 1990; Smock, 1990; Bretschko, 1991; Wagner et al., 1993; Jones et al., 1995; Naegeli et al., 1995). In some of these studies, authors have evaluated POM in the sediments by analysing the total organic carbon (TOC) without really paying attention to the relative contribution of the different size fractions (Leichtfried, 1985, 1988; Bretschko, 1991). Wagner et al. (1993) have investigated the deposition of POM over a period of 9 months, but only from the upper 3 $\mathrm{cm}$ of streambed, while Jones et al. (1995) have measured deep storage of FPOM ( $>2 \mathrm{~cm}$ depth) by digesting sediments with persulphate and analysing the resulting release of $\mathrm{CO}_{2}$. Naegeli et al. (1995) have quantified POM within the sediment, but only considered the relative contribution of POM size fractions from $<63 \mu \mathrm{m}$ to $4 \mathrm{~mm}$ (their sampling device was equipped with $4 \mathrm{~mm}$ mesh size, thereby limiting their investigations). The studies by Smock (1990) and Metzler and Smock (1990) appear as the most complete in this regard, as they were performed to measure CPOM inputs and storage both in the benthic and hyporheic compartments of headwater streams. However, they encompassed a reduced range of sediment grain-size characteristics (i.e., sandy and silt-clay bottomed streams).

Usually, fine-grained stream sediments contain larger amounts of stored detritus than streams with coarse sediments (Brunke and Gonser, 1997). However, results from the few available studies also report contradictory or less clear patterns. Therefore, conclusions that the retention of POM in sandy-bottomed streams is more efficient than in gravel bed streams must be made cautiously (Brunke and Gonser, 1997). Moreover, because of the heterogeneous nature of the sediment matrix and of discharge variability, the characteristics of the interstitial zone tend to vary widely following temporal and spatial patterns, as well as from one system to another (Brunke and Gonser, 1997).

Some studies suggest that organic matter content within the interstitial zone may be considerably higher compared with the one at the sediment surface, partly because buried organic matter has a lower decomposition rate (Herbst, 1980; Rounick and Winterbourn, 1983; Cornut et al., 2010) and is less subject to downstream transport during storms and floods. For the streams in which both benthic and hyporheic CPOM amounts have been measured, the latter account for $25-90 \%$ of the total stored organic matter (Cummins et al., 1983; Metzler and Smock, 1990). Therefore, the hyporheic zone is potentially a major site for organic matter storage, and Jones (1997) recommended considering subsurface storage in future studies to determine its importance in a range of streams. Accounting for spatial and temporal variability in organic matter storage is also needed to better understand the mechanisms that control the structure and functioning of these ecosystems.

The present study was performed to measure CPOM ( $>1 \mathrm{~mm}$ ) content in three low-order headwater streams of the Montagne Noire (South-Western France) varying in grain-size characteristics. The spatial variability of CPOM contents, above and within stream sediments, was examined at two different sampling dates (late autumn and early spring). The following hypotheses have been tested: (1) a substantial part of CPOM should be stored within streambed sediments and (2) the relative importance of allochthonous organic matter stored in interstitial versus benthic habitats should differ among streams, notably due to contrasting grain-size characteristics of their streambed.

\section{Methods}

The study was carried out in the Montagne Noire, South-Western France, a $1450-\mathrm{km}^{2}$ region covered by a mixed broadleaf forest with an altitudinal range of 250-1211 m a.s.1. Climatic conditions are marked by high rainfall (average $1500 \mathrm{~mm}_{\text {.year }}^{-1}$ ). Three first- or secondorder permanent streams with similar physical and chemical characteristics were selected in forested areas, situated between $02^{\circ} 09^{\prime} 25^{\prime \prime} \mathrm{E}$ and $02^{\circ} 19^{\prime} 51^{\prime \prime} \mathrm{E}$ longitude and $43^{\circ} 21^{\prime} 15^{\prime \prime} \mathrm{N}$ and $43^{\circ} 27^{\prime} 03^{\prime \prime} \mathrm{N}$ latitude. The riparian zones are covered by broadleaf forests dominated by oak (Quercus petraea (Mattus.) Liebl.), hazel (Corylus avellana L.), alder (Alnus glutinosa (L.) Gaertn.), ash (Fraxinus excelsior L.), sweet chestnut (Castanea sativa Mill.) and beech (Fagus silvatica L.). Tree density along the three stream reaches $\left(0.42-0.44 \mathrm{~m}^{-1}\right.$, in the Béal and the Bergnassonne, respectively; $>0.15 \mathrm{~m}$ diameter at breast height, $5 \mathrm{~m}$ stream distance) and canopy cover of the streambed $(85-95 \%$, in the Béal and the Bergnassonne, respectively) were similar.

Water chemistry was determined at two sampling dates (i.e., late autumn: 25 November 2009 and early spring: 21 March 2010), in three representative riffles per stream, both at the surface of the sediment, and in the interstitial zone (i.e., at $15 \mathrm{~cm}$ below the sediment surface) with a specific sampling device using a hand-held vacuum pump. PVC cylinders (10 $\mathrm{cm}$ length and $12 \mathrm{~mm}$ inner diameter) were pierced $(2.5 \mathrm{~mm}$ diameter hole $\times 50)$ and capped at bottom with a plastic stopper. A length of plastic tubing (Tygon, $5 \mathrm{~mm}$ inner diameter) was hermetically sealed at the top of each cylinder to allow sampling of interstitial water, and kept isolated from surface water with a clamp. Two cylinders were carefully introduced in the sediment of 
each of three representative riffles per stream, by using a piezometer pushed to $20 \mathrm{~cm}$ depth into streambed using an internal metallic rod, as described in Baxter et al. (2003). The middle of each cylinder was approximately $15 \mathrm{~cm}$ below the streambed surface. The cylinders were installed several months before water sampling to allow the initial hydraulic properties to stabilize, thereby avoiding any bias due to exchanges between surface and interstitial waters. At each sampling date, $250 \mathrm{~mL}$ of interstitial water per riffle was slowly collected from cylinders with the hand vacuum pump placed at the end of the Tygon tubing. Temperature, $\mathrm{pH}$, conductivity and dissolved oxygen concentration were measured in the field using portable instruments (pH-meter 320i and Oxi 330i, WTW, Weilheim, Germany; Conductimeter Dist5, HANNA, Woonsocket, Rhode Island, USA). Water samples were filtered in the field with $0.7 \mu \mathrm{m}$ glass fibre filters (Glass fibre GF/F, Whatman, Clifton, New Jersey, USA), stored in pre-rinsed polyethylene bottles and placed in an icebox until they were returned to the laboratory. Concentrations of $\mathrm{PO}_{4}$ measured as soluble reactive phosphorus (SRP), $\mathrm{NO}_{3}, \mathrm{NO}_{2}$ and $\mathrm{NH}_{4}$, were determined using standard colorimetric methods by flow injection analysis with an Alpkem Flow Solution IV system (OI Analytical, College Station, Texas, USA). Alkalinity was determined using potentiometric titration.

In the rivers studied, the channel consists of a sparsely extended sediment layer ( $c a .15 \mathrm{~cm}$ on average) above an impermeable layer (bedrock). Also, the interstitial zone only occurs below the streambed, but not laterally into the parafluvial zone below the banks and floodplain. Thus, the lateral expansion of the interstitial zone into the stream banks was not considered. Therefore, the interstitial zone is influenced and exclusively maintained by advected surface water.

CPOM at the channel surface and subsurface was quantified using a Surber net $(30 \mathrm{~cm} \times 30 \mathrm{~cm} ; 500 \mu \mathrm{m}$ mesh size) and a coring device similar to those described previously by Cummins (1962), Metzler and Smock (1990) and Smock (1990). The corer used in our study (80 $\mathrm{cm}$ length $\times 16 \mathrm{~cm}$ inner diameter) was specially designed to sample sediments to a depth of $15 \mathrm{~cm}$ below the streambed surface (i.e., the average depth of the whole sediment layer before bedrock is encountered). This allowed us to obtain a complete estimation of the organic matter stored in the interstitial zone.

The amount of CPOM stored in the sediment and that accumulated at the sediment surface were referred to the same surface area basis $\left(1 \mathrm{~m}^{2}\right)$. The number of samples has been doubled for the subsurface zone compared with those made at the surface of the sediment to partly compensate for the difference in surface areas sampled by both devices (i.e., Surber net: $0.09 \mathrm{~m}^{2}$ and corer: $0.02 \mathrm{~m}^{2}$ ). Thus, three samples at the sediment surface and six in the interstitial zone have been collected at each of the three selected riffles in the three streams. Each riffle has been virtually divided into nine zones (i.e., 3 sections in the length $\times 3$ zones in the width). Random selection of one sampling zone at each of the three streams was previously achieved at the laboratory by using computer software, before to be sampled. Before each sediment sampling, all CPOM at the surface of the sediment was carefully removed and discarded.

Sediments and detritus including fine and coarse POM were cautiously excavated to a depth of $15 \mathrm{~cm}$, using the PVC corer to prop up the edges of the hole and divert the water current. In addition, a hand vacuum pump with silicon tubing (10 $\mathrm{mm}$ inner diameter) was used to collect remaining organic matter in suspension and at the bottom of the hole before removing the coring device. Samples from both benthic and interstitial zones were stored individually in plastic zip-lock bags and transported to the laboratory in an icebox.

At the laboratory, organic matter was elutriated from the sediment sample by repeated washes and all material retained on a $1 \mathrm{~mm}$ sieve (CPOM) was sorted and divided into three categories as proposed by Minshall et al. (1983): $>16,4-16$ and $1-4 \mathrm{~mm}$. Once the organic matter had been removed from each grain size fraction, each sediment core was meticulously washed and wet-sieved through a series of mesh sizes $(20,10,5,2,1,0.5$ and $0.25 \mathrm{~mm})$.

The CPOM of each category and the remaining sediment from each grain size were placed into an oven at $105^{\circ} \mathrm{C}$ until constant mass and weighed to the nearest 0.01 g. CPOM contents from both surface samples (benthic zone) and sediment cores (interstitial zone) were expressed in grams of dry mass per square meter of streambed (taking into account the uppermost $15 \mathrm{~cm}$ of streambed sediment for the latter (Naegeli et al. 1995)) (Fig. 1). A non-negligible amount of POM could potentially remain within the sediment during the sieving and washing steps, especially in the finest grain size. To estimate this potential bias, the remaining organic matter has been determined by ignition (three measures per grain size fraction and per stream). This indicated that the organic matter remaining within the sediment represented less than $1 \%$ of the organic matter content, even for the finest grain size fraction.

Cumulative grain-size distribution curves (phi units) of sediments in the three streams (Fig. 1) and statistics were calculated with GRADISTAT (Blott and Pye, 2001), including the 10th, 50th and 90th percentiles, and the sorting index ( $\mathrm{Si}$ ) following the Folk and Ward method as suggested by Folk and Ward (1957) (Table 1). This index reveals the level of sediment transport: the more the sediment is submitted to a high disturbance frequency, the higher is the value of the Si (Folk and Ward, 1957). A three-way factorial analysis of variance (ANOVA) was used to assess differences in CPOM content and physicochemical variables among streams, compartment (i.e., benthic or interstitial zones) and sampling date. When significant differences were detected, Tukey HSD tests were then carried out for post-hoc pairwise comparisons. Data were log-transformed to improve homoscedasticity when necessary to meet the assumptions of ANOVA. STATISTICA 6.0 (StatSoft Inc., 2001) was used for all statistical analyses. Differences were considered significant when $P<0.05$. 


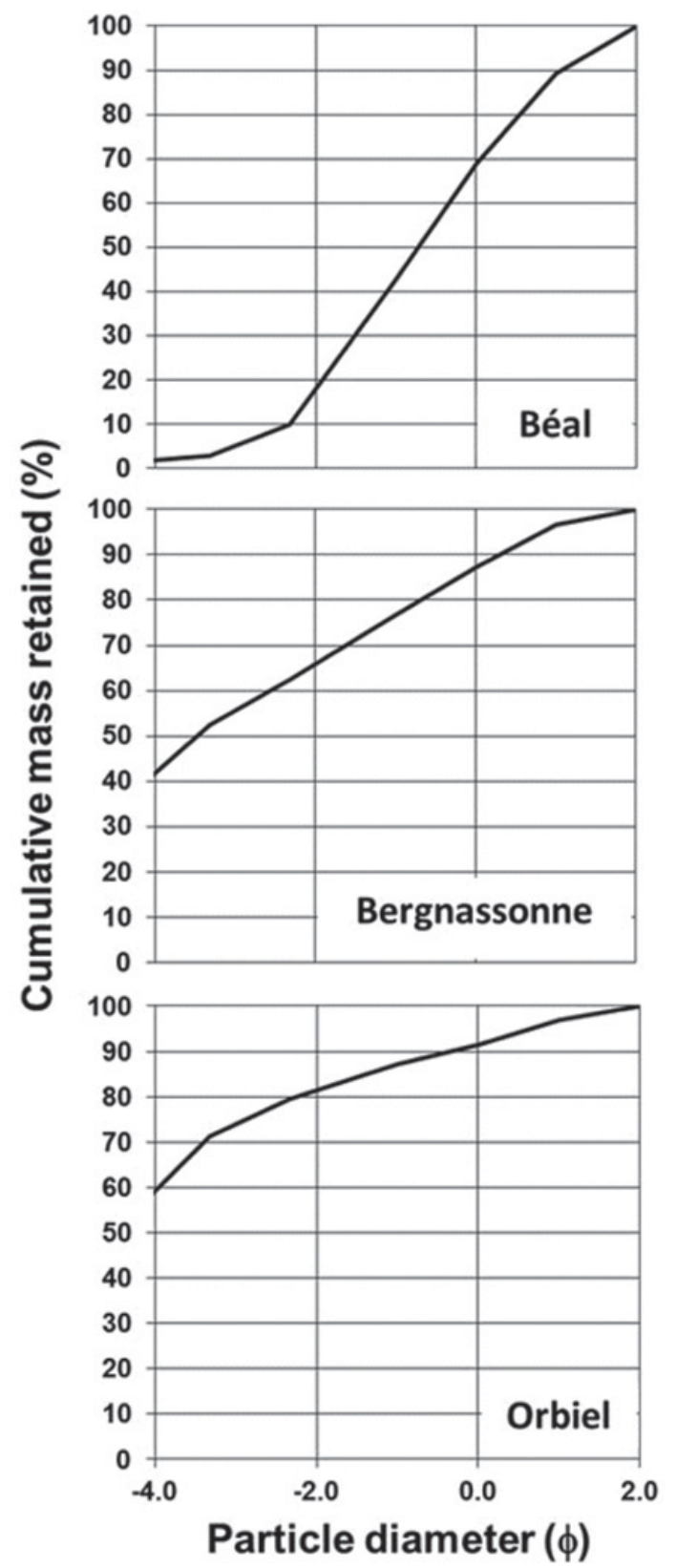

Fig. 1. Cumulative grain-size distribution curves (mean, $n=9$ per stream, phi units) of sediments in the three streams.

\section{Results}

The streams had very similar geomorphologic and hydrologic characteristics, especially in terms of water depth $(\leq 0.4 \mathrm{~m})$, width $(\leq 2.3 \mathrm{~m})$ and discharge $(75$ 166 L.s $\left.{ }^{-1}\right)$. The streambed substrata were unconsolidated and mostly made of sandy coarse gravel to coarse gravel sediments (as determined from grain size fractionation of sediment cores) for the Bergnassonne and the Orbiel, while the Béal had a streambed substratum mainly made of sand and very fine gravel (Table 1). In addition, the Si showed a narrower range of grain size in the sediments from the Orbiel (Si: 0.097) compared with the Bergnassonne (Si: 0.611 ) and, in a more pronounced manner, to the Béal
(Si: 1.397; Fig. 1). The streambed sediment of the latter is characterized by a high frequency of transport and thus disturbance. In contrast, the Orbiel sediments showed the largest range of particle size distribution, denoting their high stability. The Bergnassonne exhibited an intermediate value of Si suggesting a frequency of streambed sediment disturbance intermediary between the two others. The three stream waters were slightly acidic $(\mathrm{pH} 6.0-7.0)$ with low conductivity $\left(28-58 \mu \mathrm{S} . \mathrm{cm}^{-1}\right)$ and relatively low alkalinity (3.1-9.6 mg $\left.\mathrm{CaCO}_{3} \cdot \mathrm{L}^{-1}\right)$. Concentrations of SRP $\left(2.0-4.2 \mu \mathrm{g} . \mathrm{L}^{-1}\right)$ were low, while concentrations of $\mathrm{NO}_{3}\left(0.34-1.75 \mathrm{mg} . \mathrm{L}^{-1}\right)$ were relatively high, with significant differences among streams (ANOVA, $\left.F_{2,24}=40.88, P<10^{-6}\right)$. SRP content of interstitial waters from the three streams were systematically higher than those of surface waters (ANOVA, $F_{1,24}=6.57, P=0.02$ ). In contrast, $\mathrm{NO}_{3}$ concentration was lower in the interstitial compartment (ANOVA, $F_{1,24}=19.15, P<10^{-3}$ ). $\mathrm{NO}_{3}$ concentration in both surface and interstitial waters followed the same pattern among streams, with Béal and Bergnassonne exhibiting quite similar $\mathrm{NO}_{3}$ content, contrasting with the lower content found for Orbiel. Finally, $\mathrm{NO}_{3}$ concentrations for the three streams at the second sampling date were more than twice as high as at the first one (ANOVA, $F_{1,24}=301.81, P<10^{-6}$ ), while concentrations of SRP remained quite similar (ANOVA, $F_{1,24}=1.59, \quad P=0.22$ ). Conductivity and alkalinity of interstitial waters from the three streams were consistently higher than those of surface waters (ANOVA, $F_{1,24}=16.78, P<10^{-4}$; ANOVA, $F_{1,24}=15.28, P<10^{-4}$, respectively). At both dates, the $\mathrm{pH}$ of interstitial waters from the three streams were lower than that of surface waters (ANOVA, $F_{1,24}=54.90, P<10^{-6}$ ). Moreover, between streams, differences in terms of $\mathrm{pH}$ were more pronounced in the interstitial compared with the surface compartment, with Orbiel exhibiting the most acidic water (ANOVA, $F_{1,24}=54.90, P<10^{-3}$ ). The surface waters of the three streams were always well oxygenated (Table 1) and exhibited very similar values. Dissolved oxygen in interstitial waters was significantly lower $(51-79 \%$ of the saturation; ANOVA, $F_{2,24}=109.58, P<10^{-6}$ ), but still relatively similar among streams. The three streams differed in terms of average temperature (ANOVA, $F_{2,24}=140.51, P<10^{-6}$ ), with $9.3,7.9$ and $6.9^{\circ} \mathrm{C}$ for the Béal, the Bergnassonne and the Orbiel, respectively. Temperature was also higher in the interstitial than in the benthic zone. However, this difference (i.e., nearly $1.5^{\circ} \mathrm{C}$ ) was on average only significant for the Orbiel (ANOVA, $F_{2,24}=7.93, P<10^{-3}$ and HSD test).

CPOM content in the interstitial zone was higher than at the sediment surface (ANOVA, $F_{1,96}=7.07, P<10^{-2}$; Fig. 1 and Table 2). Indeed, it was up to one order of magnitude higher (e.g., Béal and Bergnassonne in late autumn). The total amount of CPOM markedly differed among streams (ANOVA, $F_{2,96}=6.85, P<10^{-2}$ and HSD test; Fig. 1), with the Béal followed by the Orbiel exhibiting the highest amounts of the total CPOM. The proportion of the different CPOM size fractions also strongly varied among streams. Amounts of large POM 
Table 1. Physicochemical characteristics of water from the benthic and interstitial zones of the three streams, measured at each date (late autumn and early spring, values are means $\pm \mathrm{SE}, n=6$ per stream and per compartment) and sediment physical descriptors. The d50 value represents the median grain diameter, whereas d10 and d90 represent the grain diameters at the 10th and 90 th percentile values. Si is calculated as a measure of standard deviation.

\begin{tabular}{|c|c|c|c|c|c|c|}
\hline & \multicolumn{2}{|c|}{ Béal } & \multicolumn{2}{|c|}{ Bergnassonne } & \multicolumn{2}{|c|}{ Orbiel } \\
\hline Altitude (m a.s.l.) & \multicolumn{2}{|c|}{551} & \multicolumn{2}{|l|}{700} & \multicolumn{2}{|c|}{780} \\
\hline Width (m) & \multicolumn{2}{|c|}{1.40} & \multicolumn{2}{|c|}{2.20} & \multicolumn{2}{|c|}{2.20} \\
\hline Depth (m) & \multicolumn{2}{|c|}{0.17} & \multicolumn{2}{|c|}{0.13} & \multicolumn{2}{|c|}{0.22} \\
\hline Slope $(\%)$ & \multicolumn{2}{|c|}{2.10} & \multicolumn{2}{|c|}{3.40} & \multicolumn{2}{|c|}{3.20} \\
\hline Discharge (L.s $\left.{ }^{-1}\right)$ & \multicolumn{2}{|c|}{$75-88$} & \multicolumn{2}{|c|}{$79-122$} & \multicolumn{2}{|c|}{$108-166$} \\
\hline Sediment physical descriptor & \multirow{2}{*}{\multicolumn{2}{|c|}{0.475}} & & & \\
\hline $\mathrm{d} 10(\mathrm{~mm})$ & & & \multicolumn{2}{|c|}{0.814} & \multicolumn{2}{|c|}{1.274} \\
\hline $\mathrm{d} 50(\mathrm{~mm})$ & \multicolumn{2}{|c|}{1.643} & \multicolumn{2}{|c|}{11.159} & \multicolumn{2}{|c|}{16.441} \\
\hline $\mathrm{d} 90(\mathrm{~mm})$ & \multicolumn{2}{|c|}{5.000} & \multicolumn{2}{|c|}{97.477} & 617 & \\
\hline $\operatorname{Si}(\phi)$ & \multicolumn{2}{|c|}{1.397} & \multicolumn{2}{|c|}{0.611} & \multicolumn{2}{|c|}{0.097} \\
\hline Physical-chemical variables & Benthic & Interstitial & Benthic & Interstitial & Benthic & Interstitial \\
\hline Temperature $\left({ }^{\circ} \mathrm{C}\right)$ & $9.2 \pm 0.7$ & $9.5 \pm 0.7$ & $7.6 \pm 0.1$ & $8.2 \pm 0.2$ & $6.2 \pm 0.6$ & $7.6 \pm 0.6$ \\
\hline $\mathrm{pH}$ & $6.7 \pm 0.3$ & $6.4 \pm 0.2$ & $6.3 \pm 0.3$ & $6.2 \pm 0.3$ & $6.4 \pm 0.3$ & $5.8 \pm 0.1$ \\
\hline Dissolved oxygen ( $\%$ sat.) & $99.3 \pm 1.4$ & $56.2 \pm 10.8$ & $98.3 \pm 1.7$ & $69.3 \pm 21.1$ & $99.3 \pm 2.7$ & $61.2 \pm 12.4$ \\
\hline Conductivity $\left(\mu \mathrm{S} . \mathrm{cm}^{-1}\right)$ & $56.8 \pm 3.2$ & $58.3 \pm 3.4$ & $35.2 \pm 1.2$ & $56.9 \pm 12.1$ & $28.8 \pm 2.9$ & $32.6 \pm 2.8$ \\
\hline Alkalinity $\left(\mathrm{mg} \mathrm{CaCO}_{3} \cdot \mathrm{L}^{-1}\right)$ & $9.4 \pm 0.2$ & $10.9 \pm 1.4$ & $3.8 \pm 0.7$ & $14.7 \pm 7.2$ & $3.3 \pm 0.5$ & $5.3 \pm 1.0$ \\
\hline $\mathrm{P}-\mathrm{PO}_{4}\left(\mu \mathrm{g} . \mathrm{L}^{-1}\right)$ & $3.7 \pm 1.63$ & $2.79 \pm 1.26$ & $2.01 \pm 0.04$ & $8.01 \pm 5.38$ & $2.90 \pm 1.10$ & $5.82 \pm 3.64$ \\
\hline $\mathrm{N}-\mathrm{NO}_{3}\left(\mathrm{mg} . \mathrm{L}^{-1}\right)$ & $1.25 \pm 0.50$ & $0.96 \pm 0.43$ & $1.13 \pm 0.35$ & $0.96 \pm 0.51$ & $0.71 \pm 0.37$ & $0.56 \pm 0.34$ \\
\hline $\mathrm{N}-\mathrm{NH}_{4}\left(\mu \mathrm{g} \cdot \mathrm{L}^{-1}\right)$ & $2.97 \pm 0.97$ & $18.35 \pm 6.49$ & $5.82 \pm 2.18$ & $7.87 \pm 2.61$ & $12.57 \pm 7.54$ & $6.15 \pm 2.70$ \\
\hline
\end{tabular}

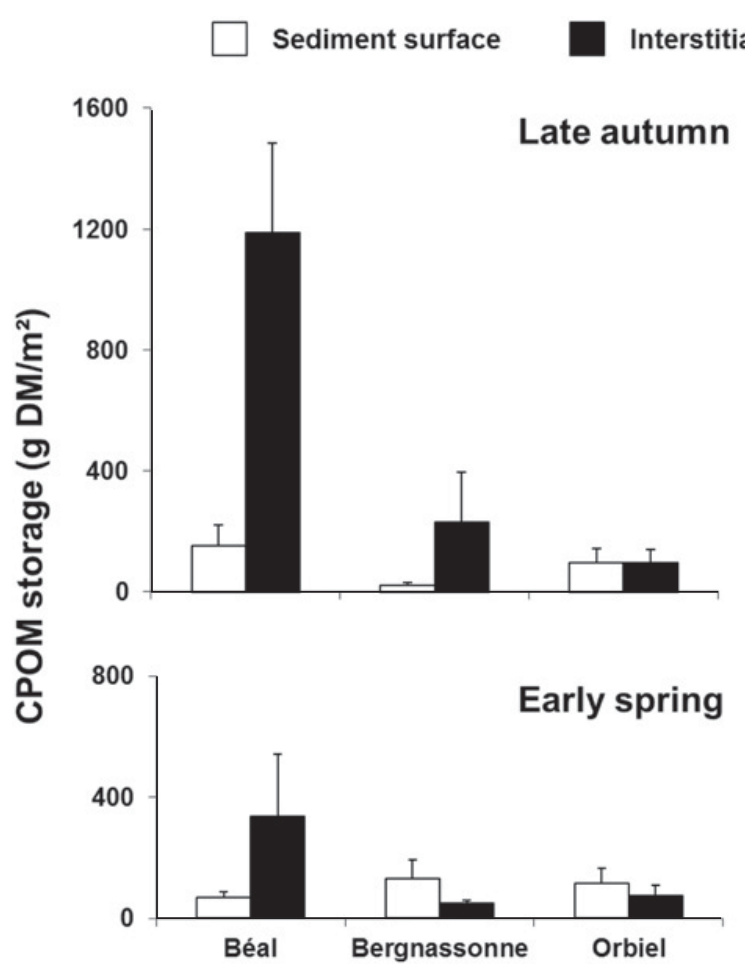

Fig. 2. Total CPOM contents ( $+\mathrm{SE}, n=9$ per stream) at the sediment surface and in the interstitial zone of the three streams.

(i.e., $>16 \mathrm{~mm}$ ) in the Béal were significantly higher than in the Bergnassonne, but did not differ from the Orbiel (ANOVA, $F_{2,96}=4.26, P=0.017$ and HSD test; Table 2). The same patterns were found for both compartments and seasons. In contrast, the amount of CPOM between 4 and
$16 \mathrm{~mm}$ was markedly higher in the interstitial zone than at the surface of sediment (ANOVA, $F_{1,96}=28.44$, $\left.P<10^{-6}\right)$. Moreover, our results showed differences among streams, with the Béal having higher amounts of this type of particles compared with the other streams (ANOVA, $F_{2,96}=4.27, P=0.016$ et HSD test). Finally, the same although more contrasted patterns were observed with the finest POM (1-4 mm). As previously, results showed marked differences among streams with once again the Béal having the higher content for this type of POM (ANOVA, $F_{2,96}=6.87, P<10^{-2}$ ), while the two other streams exhibited very similar fine POM contents. Moreover, differences in terms of fine POM contents were also found between compartments (ANOVA, $F_{1,96}=5.98$, $P=0.016$ ) and seasons (ANOVA, $F_{1,96}=15.88$, $\left.P<10^{-5}\right)$, with an higher amount in the interstitial zone in late autumn.

Table 3 shows the mean relative amount of the three CPOM size-classes, measured at the sediment surface and in the interstitial zone of the three streams. Patterns were comparable between the two sampling dates for the Béal and Orbiel taken separately, whereas the one for Bergnassonne was much less well defined. The interstitial zone of the Béal exhibited a higher amount of coarse and intermediate POM size classes (i.e., > $16 \mathrm{~mm}$ and 4-16 $\mathrm{mm}$, respectively) than the surface one, but also on average when compared with the two other streams. This pattern was much more contrasted with regard to the finest POM size class. Interestingly, the amounts of POM for intermediate and fine size-classes were relatively higher in the interstitial than in the benthic zone of Orbiel, while the coarsest POM showed the opposite pattern. Finally, it was difficult to identify any trend for the Bergnassonne, 
Table 2. Summary of the results from three-way ANOVAs performed on the total amount of CPOM and the three CPOM size classes, measured at each date (late autumn and early spring) at the sediment surface and in the interstitial zone of the three streams.

\begin{tabular}{|c|c|c|c|c|c|c|c|c|c|c|c|c|}
\hline \multirow[b]{2}{*}{ Analysis } & \multicolumn{3}{|c|}{$\mathrm{CPOM}>16 \mathrm{~mm}$} & \multicolumn{3}{|c|}{$\mathrm{CPOM}=4-16 \mathrm{~mm}$} & \multicolumn{3}{|c|}{$\mathrm{CPOM}=1-4 \mathrm{~mm}$} & \multicolumn{3}{|c|}{ Total CPOM } \\
\hline & $\overline{\mathrm{df}}$ & $F$ & $P$ & $\mathrm{df}$ & $F$ & $P$ & df & $F$ & $P$ & $\overline{\mathrm{df}}$ & $F$ & $P$ \\
\hline \multicolumn{13}{|l|}{ Three-way ANOVA } \\
\hline Intercept & 1 & 229.9 & $<0.001$ & 1 & 409.0 & $<0.001$ & 1 & 499.8 & $<0.001$ & 1 & 873.1 & $<0.001$ \\
\hline Stream & 2 & 4.3 & 0.017 & 2 & 4.3 & 0.016 & 2 & 6.9 & 0.002 & 2 & 6.8 & 0.002 \\
\hline Date & 1 & 1.1 & 0.290 & 1 & 4.1 & 0.046 & 1 & 15.9 & $<0.001$ & 1 & 1.4 & 0.234 \\
\hline Compartment & 1 & 0.2 & 0.651 & 1 & 28.4 & $<0.001$ & 1 & 6.0 & 0.016 & 1 & 7.1 & 0.009 \\
\hline Stream $\times$ date & 2 & 1.3 & 0.276 & 2 & 2.6 & 0.083 & 2 & 7.6 & $<0.001$ & 2 & 3.7 & 0.029 \\
\hline Stream $\times$ compartment & 2 & 2.0 & 0.138 & 2 & 1.3 & 0.230 & 2 & 2.0 & 0.140 & 2 & 3.4 & 0.03 \\
\hline Date $\times$ compartment & 1 & 0.3 & 0.617 & 1 & 1.7 & 0.190 & 1 & 63.8 & $<0.001$ & 1 & 6.1 & 0.015 \\
\hline Stream $\times$ date $\times$ compartment & 2 & 0.3 & 0.759 & 2 & 0.8 & 0.444 & 2 & 2.0 & 0.147 & 2 & 1.2 & 0.305 \\
\hline Error & 96 & & & 96 & & & 96 & & & 96 & & \\
\hline
\end{tabular}

Table 3. Relative contribution (\%) of the benthic and interstitial zones to the amount of three size-classes of CPOM stored in the three streams (mean of 9 replicates per zone, date and stream).

\begin{tabular}{|c|c|c|c|c|c|c|}
\hline \multirow[b]{2}{*}{ CPOM size-classes } & \multicolumn{2}{|c|}{ Béal } & \multicolumn{2}{|c|}{ Bergnassonne } & \multicolumn{2}{|c|}{ Orbiel } \\
\hline & Benthic & Interstitial & Benthic & Interstitial & Benthic & Interstitial \\
\hline \multicolumn{7}{|l|}{ Late autumn } \\
\hline$>16 \mathrm{~mm}$ & 15.3 & 84.7 & 10.1 & 89.9 & 86.3 & 13.7 \\
\hline 4-16 mm & 11.3 & 88.7 & 7.1 & 92.9 & 10.8 & 89.2 \\
\hline $1-4 \mathrm{~mm}$ & 5.0 & 95.0 & 8.2 & 91.8 & 14.1 & 85.9 \\
\hline \multicolumn{7}{|l|}{ Early spring } \\
\hline$>16 \mathrm{~mm}$ & 27.8 & 72.2 & 66.5 & 33.5 & 74.4 & 25.6 \\
\hline 4-16 mm & 9.2 & 90.8 & 38.9 & 61.1 & 35.1 & 64.9 \\
\hline $1-4 \mathrm{~mm}$ & 79.4 & 20.6 & 84.2 & 15.8 & 42.0 & 58.0 \\
\hline
\end{tabular}

partly due to the contrasted patterns between the two sampling dates.

\section{Discussion}

\section{CPOM in benthic versus interstitial zones}

To our knowledge, this is the first study in France that attempted to evaluate the CPOM content both in the benthic and interstitial zones of headwater streams. More generally, as reported by Jones (1997), most studies of organic matter storage remain limited to the benthic layer, whereas the interstitial zone potentially constitutes a significant site for organic matter storage (Metzler and Smock, 1990; Smock, 1990; Naegeli et al. 1995). Despite a high variability between streams, the present study demonstrated that the amounts of CPOM buried in the sediment were far to be negligible. Generally, these amounts for the three streams were even higher or equivalent to those at the surface of the sediment (Fig. 1). For instance, the CPOM stored in the Beal and the Bergnassonne in late autumn was up to one order of magnitude higher in the interstitial zone than in the benthic one. The highest amounts were found in the Béal, a sandy bottomed stream, where almost $1.2 \mathrm{~kg} \mathrm{DM.m}{ }^{-2}$ was retained in the subsurface. This value is lower than those reported by Metzler and Smock (1990) and Smock (1990), with 4.8 and almost $2.9 \mathrm{~kg} \mathrm{AFDM.m}{ }^{-2}$, respectively. However, our value derived from punctual assessments of CPOM contents, in contrast to the cited studies reporting cumulated amounts of CPOM buried in the sediment over 1 year.

\section{Dynamics of CPOM in the interstitial zone}

The spatio-temporal distribution and the total amount of detritus stored in streams are not only related to terrestrial organic matter production, but are also dependent on the detritus retention mechanisms (Jones, 1997). General characteristics of streams in terms of grain-size substrate, hydrology, watershed morphology and slope are likely to affect detritus retention in streams. Our streams were fairly similar in terms of riparian cover density, slope and water discharge, suggesting a prime role of sediment grain-size in controlling the amount of stored CPOM. Leaf retention and organic matter storage at the surface of sediments in streams generally increase with sediment grain size and bed roughness (Webster et al., 1987). Due to the lack of obstruction at the surface of sediments, sandybottomed streams usually retain and store POM much less efficiently. In the present study, based solely on two snapshot samplings, the sandy-bottomed stream (i.e., Béal) did not exhibit a different retention of CPOM in the benthic zone when compared with the two other streams, which yet showed contrasted substrate grain sizes. An examination of the $\mathrm{Si}$ in Table 1 reveals a 
narrower range of grain size in the sediments from the Béal than from the two other streams. Figure 1 shows that the subsurface CPOM content is positively related to the $\mathrm{Si}$ and consequently to the disturbance frequency of the superficial layer of streambed sediment. Although POM retention in the interstitial zone may be related to factors other than sediment grain size (Brunke and Gonser, 1997), our results and several other studies confirm that finegrained stream sediments generally contain larger amounts of stored detritus than streams with coarser sediments (Leichtfried, 1985; Metzler and Smock, 1990; Wagner et al., 1993). However, the potentially lower decomposition rate of CPOM in the sandy sediments of the Béal stream compared with other streams might also explain, at least partially, the higher storage of POM in the first. Indeed, burial within the substratum might impede shredders' access to leaves with the small interstitial pore spaces of the sandy sediment acting as a physical barrier, especially for the large-bodied shredders, often identified in temperate streams as being the element of decomposers consortium playing the most critical role in leaf litter decomposition (Hieber and Gessner, 2002). Conversely, large grain size is likely to permit interstitial spaces large enough to be colonized by large-bodied shredders able to drive the decomposition process of CPOM.

An examination of Figure 1 reveals that the CPOM stock was temporally variable. Indeed, CPOM content in subsurface at our second sampling date (early spring) was markedly lower when compared with the previous one, however, these differences were not statistically significant, probably because of the high variability in the Béal. This high variability in the sandy-bottomed stream is not surprising and may be partly explained by sediment instability, which is the function of particle size. The interstitial zone of sandy-bottomed streams is generally characterized by a higher disturbance frequency, increasing its potential to store large quantities of organic matter, and a higher spatial and temporal variability of organic matter stored.

These changes in the pool of interstitial detritus may be explained both by their processing, even though rates remain generally much lower than at the surface of the sediment (Herbst, 1980; Rounick and Winterbourn, 1983; Metzler and Smock, 1990; Cornut et al., 2010), and by their transport after they have been released from subsurface as demonstrated in the study by Metzler and Smock (1990). These authors reported that high discharge and associated bedload movement due to a flood in late summer had dramatically reduced the amount of stored organic matter by scour removing 612 g.m $\mathrm{m}^{-2}$ of detritus from the sediment at that time. Thus, and in line with the few studies that have quantified CPOM amounts in the interstitial habitat, our findings demonstrate that burial can be an important storage mechanism, particularly in streams with loose sediment and potentially high sediment disturbance frequency (Herbst, 1979; Godbout and Hynes, 1982; Cummins et al., 1983; Metzler and Smock, 1990).
In temperate forested streams, most litter inputs occur in autumn after leaf abscission, i.e., during high discharge and surface runoff following high rainfall in the autumn and winter, even though a substantial part of detritus from the stream banks and the adjacent zones may also be subject to lateral movement and therefore continue entering streams over the whole year (Benfield, 1997). In parallel, as reported by Brunke and Gonser (1997) and Naegeli et al. (1995), even though, usually most of the fine and coarse POM are carried in the sediments during floods (i.e., late autumn and winter), Bretschko and Moser (1993) demonstrated that in a porous gravel stream more than $80 \%$ of the annual POM input was transported into the sediment in spring and summer during high discharge fluctuations, while a small proportion (i.e., <10\%) entered after litter fall. In the same line, Wagner et al. (1993) reported that organic matter content of the sediment in a small forested sandy-bottomed stream in Germany was inversely related to the discharge. Thus, as reported in the present study and previous works, the peak amount of POM in the interstitial zone of headwater streams is closely related to the nature of the streambed substrate, stream hydrology (e.g., high discharge fluctuation and current velocity) and meteorological events (Fig. 3), and is likely to occur more or less later, after litter fall and thus the maximum availability of POM in the benthic compartment.

As demonstrated by Metzler and Smock (1990), the spatio-temporal distribution of detritus stored in the interstitial zone is also likely subject to the vertical dimension. Consequently, the total interstitial POM storage can be divided into two components, i.e., the shallow and deep ones. Shallow storage only refers to the upper layer of sediment (i.e., several top centimetres) involving POM frequently buried and released likely due to sediment instability and high disturbance frequency. Conversely, deep POM storage encompasses detritus deposited below the shallow layer occasionally scoured during rare high-flow events related to storms (Herbst, 1980) or as a consequence of prolonged heavy rainfalls, which are both expected to increase over the next few decades according to the simulations made by the IPCC (Intergovernmental Panel on Climate Change) (2007) assuming a doubling of atmospheric $\mathrm{CO}_{2}$ concentrations by the year 2100 . Low-gradient streams exhibiting loose, shifting streambed sediment and deeper hyporheic sediments are likely subject to deep POM storage and therefore much higher interstitial POM storage than surface storage when compared with high-gradient streams with coarser sediments and much less extended hyporheic zone (Godbout and Hynes, 1982; Cummins et al. 1983; Metzler and Smock, 1990). Therefore, POM deeply stored in the interstitial zone may not be released for years due to both physical immobilization and the much slower decomposition occurring in the interstitial sediment partially explained by the often anoxic conditions (Metzler and Smock, 1990), thus resulting in decreased carbon spiralling lengths (Newbold et al., 1982). In higher-gradient streams, the predominance of 


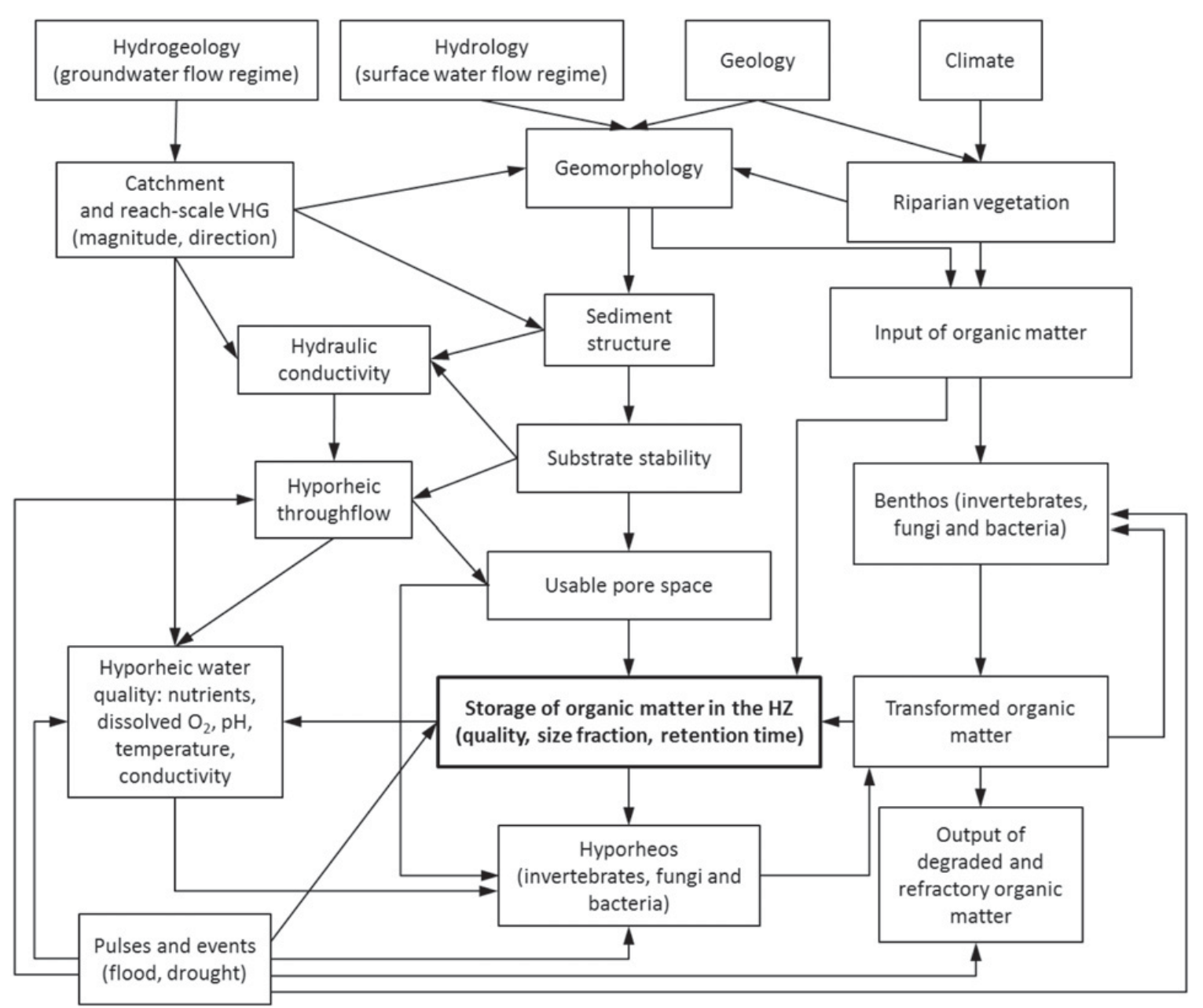

Fig. 3. Factors affecting the CPOM storage in the hyporheic zone (HZ) of headwater streams (adapted from Boulton et al., 2010; Brunke and Gonser, 1997).

POM shallow storage may, on the contrary, increase the carbon spiralling lengths through the faster release of total immobilized carbon sources, potentially leading to a lower in-stream stabilization of energy flow. The vertical dimension, depending on its extent, by releasing new carbon sources plays a potentially significant role in the overall stream metabolism.

\section{Functional significance of buried CPOM}

Organic matter provides the basis of the energy driving nutrient cycles within lotic aquatic ecosystems. The decomposition of this organic matter involves the activities of both microbial and invertebrate decomposers (Gessner and Chauvet, 1994; Suberkropp, 1998; Graça, 2001; Hieber and Gessner, 2002). With regard to our results and previous studies (Maridet et al., 1992, 1996; Strayer et al., 1997), due to the temporal disconnection that may occur between the maximum of stored POM in the benthic and interstitial compartments, we hypothesized that vertical and active migration of aquatic invertebrates between the channel and the interstitial zone should occur, especially at times when supplies from the surface are scarce and accumulated detritus represent large quantities of new carbon sources. Organic matter storage within the interstitial zone of streams leads to carbon retention and reduced transport downstream. This process seems to be particularly significant in sandy-bottomed streams where organic matter storage on the streambed surface is relatively inefficient, a feature that is exacerbated during floods (Smock et al., 1989). The interstitial storage thus affects carbon spiralling lengths (Newbold et al., 1982), both the transport and biological utilization components of spiralling being decreased when compared with situations where processes are limited to surface waters. The lower microbial and invertebrate utilization of buried organic matter compared with the surface is, however, potentially important for the overall stream metabolism (Grimm and Fisher, 1984; Cornut et al., 2010), in particular through the delayed release of dissolved organic carbon and nutrients (Crocker and Meyer, 1987). More generally, this non-negligible amount of decomposing organic matter buried in the sediments, together with a more or less reduced water's travel time in the interstitial zone depending on numerous factors such 
as geomorphology, sediment structure and hydraulic conductivity (Fig. 3), are likely to affect the physicochemical characteristics of interstitial water (Table 1). The low levels of $\mathrm{NH}_{4}$ in the three studied streams both in interstitial and benthic compartments can reflect the low level of mineralization of POM through the microbial activities and/or the availability of dissolved oxygen due to adequate water exchange, providing the required conditions for nitrifying bacteria to oxidize ammonium to nitrate. In parallel, leaf litter decomposition buried in the sediment occurs with a lower rate when compared with the surface environment (Herbst, 1980; Rounick and Winterbourn, 1983; Metzler and Smock, 1990; Cornut et al., 2010). Then, CPOM once buried in the sediment is temporarily removed from the surface system. However, because of biogeochemical activities in the interstitial zone, transformed nutrients and fine POM are released into the groundwater and stream water depending on the direction and magnitude of vertical hydrological exchanges (Vervier et al., 1992). Thus, the interstitial zone may serve as a temporary reservoir for organic matter in streams and affect the overall pattern of stream metabolism.

\section{Future prospects}

As suggested by Jones (1997) more than a decade ago, our understanding of CPOM storage in the interstitial zone of streams still remains limited in several aspects. First, while hydrology at the stream scale has been shown to rule POM storage, local vertical hydraulic gradients at a smaller scale (i.e., riffle-scale) can also be determinant. Research in this area is needed to compare patterns and processes in upwelling and downwelling zones; while exfiltration is likely to prevent deposition of fine particle, infiltration may result in interstitial pores being filled (Brunke and Gonser, 1997). Second, storms and associated spates represent brief but ecologically relevant events. In line with Cummins et al. (1983), Webster and Meyer (1997) and Tank et al. (2010), who suggest to include the rare - but determinant - high-discharge events in measurements of organic matter transport, we suggest to consider subsurface storage (i.e., uppermost and deep sediment layers) in the construction of organic matter budgets. Third, inputs of CPOM, such as leaf litter, are mainly influenced by the occurrence and the type of riparian vegetation (Maridet et al., 1996, 1997), with streams draining forested watershed receiving higher POM inputs than streams from non-forested areas (Tank et al., 2010). Similarly, forestry practices tend to alter the quantity, quality and timing of POM inputs in streams. Consequences of such practices, as well as other anthropogenic alterations, must now also be evaluated in the subsurface compartment of streams, which may be more sensitive than the surface one and contribute to the whole stream ecosystem's resilience. Finally, being aware that the generalization of our findings is limited by our approach relying on two sampling dates, we suggest to extend study periods beyond 1 year. As organic matter production and input vary across years due to extreme events such as flooding or droughts (Smock et al., 1994), stored detritus in streams are also influenced by this variability (Jones, 1997). A multi-year budget-based approach would bring interesting insights into the effects of plant phenology and meteorological conditions that control the timing of leaf fall and thus the dynamics of allochthonous organic matter entering surface and subsurface compartments of streams.

Acknowledgements. We thank Felix Bärlocher, Manuel Graça, François Guérold, Florian Mermillod-Blondin and two anonymous reviewers whose comments led to significant improvements of the manuscript. We are grateful to Virginie Payre and Fréderic Julien for their expert technical assistance. This study was funded through the InBioProcess project of the ANR Biodiversity programme (ANR-06-BDIV-007).

\section{References}

Baxter C., Hauer R.F. and Woessner W.W., 2003. Measuring groundwater-stream water exchange: new techniques for installing minipiezometers and estimating hydraulic conductivity. Trans. Am. Fish. Soc., 132, 493-502.

Benfield E.F., 1997. Comparisons of litterfall input to streams. J. N. Am. Benthol. Soc., 16, 104-108.

Blott S.J. and Pye K., 2001. Gradistat: A grain size distribution and statistics package for the analysis of unconsolidated sediments. Earth Surf. Proc. Land., 26, 1237-1248.

Boulton A.J., 2000. River ecosystem health down under: assessing ecological condition in riverine groundwater zones in Australia. Ecosyst. Health, 6, 108-118.

Boulton A., Datry T., Kasahara T., Mutz M. and Stanford J., 2010. Ecology and management of the hyporheic zone: stream-groundwater interactions of running waters and their floodplains. J. N. Am. Benthol. Soc., 29, 26-40.

Bretschko G., 1991. The limnology of a low order alpine gravel stream (Ritrodat-Lunz study area, Austria). Verh. Internat. Verein. Limnol., 24, 1908-1912.

Bretschko G. and Moser H., 1993. Transport and retention of matter in riparian ecotones. Hydrobiologia, 251, 95-101.

Brunke M. and Gonser T., 1997. The ecological significance of exchange processes between rivers and groundwater. Freshwater Biol., 37, 1-33.

Cornut J., Elger A., Lambrigot D., Marmonier P. and Chauvet E., 2010. Early stages of leaf decomposition are mediated by aquatic fungi in the hyporheic zone of woodland streams. Freshwater Biol., 55, 2541-2556.

Crocker M.T. and Meyer J.L., 1987. Interstitial dissolved organic carbon in sediments of a southern Appalachian headwater stream. J. N. Am. Benthol. Soc., 6, 159-167.

Cummins K.W., 1962. An evaluation of some techniques for the collection and analysis of benthic samples with special emphasis on lotic waters. Am. Midl. Nat., 67, 477-504.

Cummins K.W., Sedell J.R., Swanson F.J., Minshall G.W., Fisher S.G., Cushing C.E., Petersen R.C. and Vannote R.L., 1983. Organic matter budgets for stream ecosystems: problems in their evaluation. In: J.R. Barnes and G.W. 
Minshall (eds.), Stream Ecology. Application and Testing of General Ecological Theory, Plenum Press, New York, 299-353.

Cummins K.W., Wilzbach M.A., Gates D.M., Perry J.B. and Taliaferro W.B., 1989. Shredders and riparian vegetation. Bioscience, 39, 24-30.

Folk R.L. and Ward W.C., 1957. Brazos River bar: a study in the significance of grain size parameters. J. Sediment. Petrol., 27, $3-26$.

Gessner M.O. and Chauvet E., 1994. Importance of microfungi in controlling breakdown rates of leaf litter. Ecology, 75, $1807-1817$.

Gibert J., Dole-Olivier M.-J., Marmonier P. and Vervier P., 1990. Surface water-groundwater ecotones. In: R.J. Naiman and H. Décamps (eds.), The Ecology and Management of Aquatic-Terrestrial Ecotones, United Nations Educational, Scientific, and Cultural Organization, Paris and Parthenon Publishers, Carnforth, UK, 199-226.

Godbout L. and Hynes H.B.N., 1982. The three-dimensional distribution of the fauna in a single riffle in a stream in Ontario. Hydrobiologia, 97, 87-96.

Graça M.A.S., 2001. The role of invertebrates on leaf litter decomposition in streams - a review. Int. Rev. Hydrobiol., 86, 383-393.

Grimm N.B. and Fisher S.G., 1984. Exchange between interstitial and surface waters: implications for stream metabolism and nutrient cycling. Hydrobiologia, 111, 219-228.

Herbst G.N., 1979. Detrital leaf dynamics in a lowland forest stream. Ph.D. Dissertation, University of Wisconson, Madison, WI, USA, $191 \mathrm{p}$.

Herbst G.N., 1980. Effects of burial on food value and consumption of leaf detritus by aquatic invertebrates in a lowland forest stream. Oikos, 35, 411-424.

Hieber M. and Gessner M.O., 2002. Contribution of stream detritivores, fungi, and bacteria to leaf breakdown based on biomass estimates. Ecology, 83, 1026-1038.

IPCC (Intergovernmental Panel on Climate Change) (2007) Climate Change 2007: The Physical Science Basis. Contribution of the Working Group I to the Fourth Assessment Report of the Intergovernmental Panel on Climate Change, Cambridge University Press, Cambridge, UK.

Jones J.B., 1997. Benthic organic matter storage in streams: influence of detrital import and export, retention mechanisms, and climate. J. N. Am. Benthol. Soc., 16, 109-119.

Jones J.B., Fisher S.G. \& Grimm N.B., 1995. Vertical hydrologic exchange and ecosystem metabolism in a Sonoran Desert stream. Ecology, 76, 942-952.

Kaushik N.K. and Hynes H.B.N., 1971. The fate of the dead leaves that fall into streams. Arch. Hydrobiol., 68, 465-515.

Keller E.A. and Swanson F.J., 1979. Effects of large organic material on channel form and fluvial processes. Earth Surf. Process., 4, 361-380.

Leichtfried M., 1985. Organic matter in gravel streams (Project Ritrodat-Lunz). Verh. Internat. Verein. Limnol., 22, 20582062.

Leichtfried M., 1988. Bacterial substrates in gravel beds of a second order alpine stream (Project Ritrodat-Lunz). Verh. Internat. Verein. Limnol., 23, 1325-1332.

Malmqvist B., Nilsson L.M. and Svensson B.S., 1978. Dynamics of detritus in a small stream in southern Sweden and its influence on the distribution of the bottom animal communities. Oikos, 31, 3-16.
Maridet L., Wasson J.-G. \& Phillippe M., 1992. Vertical distribution of fauna in the bed sediment of three running water sites: influence of physical and trophic factors. Regul. Rivers: Res. Manage., 7, 45-55.

Maridet L., Phillippe M., Wasson J.-G. and Mathieu J., 1996. Spatial and temporal distribution of macroinvertebrates and trophic variables within the bed sediment of three streams differing by their morphology and riparian vegetation. Arch. Hydrobiol., 136, 41-64.

Maridet L., Philippe M., Wasson J.-G. and Mathieu J., 1997. Seasonal dynamics and storage of particulate organic matter within bed sediment of three streams with contrasted riparian vegetation and morphology. In: Gibert J., Mathieu J. and Fournier F. (eds.), Groundwater/Surface Water Ecotones: Biological and Hydrological Interactions and Management Options, Cambridge University Press, Cambridge: 68-74.

Metzler G.M. and Smock L.A., 1990. Storage and dynamics of subsurface detritus in a sandbottomed stream. Can. J. Fish. Aquat. Sci., 47, 588-594.

Minshall G.W., Petersen R.C., Cummins K.W., Bott T.L., Kenneth W., Sedell J.R., Cushing C.E., and Vannote R.L., 1983. Interbiome Comparison of Stream Ecosystem Dynamics. Ecol. Monogr., 53, 1-25.

Naegeli M.W., Hartmann U., Meyer E.I. and Uehlinger U., 1995. POM-dynamics and community respiration in the sediments of a floodprone prealpine river (Necker, Switzerland). Arch. Hydrobiol., 133, 339-347.

Newbold J.D., Elwood J.W., O’Neill R.V., and Van Winkle W., 1981. Measuring nutrient spiralling in streams. Can. J. Fish. Aquat. Sci., 38, 860-863.

Newbold J.D., Mulholland P.J., Elwood J.W. and O'Neill R.V., 1982. Organic carbon spiralling in stream ecosystems. Oikos, $38,266-272$.

Orghidan T., 1959. Ein neuer Lebensraum des unterirdischen Wassers: der hyporheische Biotop. Arch. Hydrobiol., 55, 392-414.

Rounick J.S. and Winterbourn M.J., 1983. Leaf processing in 2 contrasting beech forest streams - effects of physical and biotic factors on litter breakdown. Arch. Hydrobiol., 96, 448-474.

Schwoerbel J., 1961. Über die Lebensbedingungen und die Besiedlung des hyporheischen Lebensraumes. Arch. Hydrobiol. Suppl., 25, 182-214.

Schwoerbel J., 1964. Die Wassermilben (Hydrachnellae und Limnohalacaridae) als Indikatoren einer biozonotischen Gliederung von Breg und Brigach sowie der obersten Donau. Arch. Hydrobiol. Suppl., 27, 386-417.

Short R.A. and Ward J.V., 1981. Benthic detritus dynamics in a mountain stream. Ecography, 4, 32-35.

Smock L.A., 1990. Spatial and temporal variation in organic matter storage in low-gradient, headwater streams. Arch. Hydrobiol., 118, 169-184.

Smock L.A., Metzler G.M. and Gladden J.E., 1989. Role of debris dams in the structure and functioning of low-gradient headwater streams. Ecology, 70, 764-775.

Smock L.A., Smith L.C., Jones J.B. and Hooper S.M., 1994. Effects of drought and a hurricane on a coastal headwater stream. Arch. Hydrobiol., 131, 25-38.

Sobczak W.V., Hedin L.O., and Klug M.J., 1998. Relationships between bacterial productivity and organic carbon at a soilstream interface. Hydrobiologia, 386, 45-53. 
StatSoft Inc., 2001. Statistica 6.0: Electronic Statistics Textbook. Available at: http://www.statsoft.com/textbook/stathome. html

Strayer D.L., May S.E., Nielsen P., Wollheim W. and Hausam S., 1997. Oxygen, organic matter, and sediment granulometry as controls on hyporheic animal communities. Arch. Hydrobiol., 140, 131-144.

Suberkropp K., 1998. Microorganisms and organic matter processing. In: Naiman R.J. and Bilby R.E. (eds.), River Ecology and Management: Lessons from the Pacific Coastal Ecoregion, Springer-Verlag, New York, 120-143.

Tank J.L., Rosi-Marshall E.J., Griffiths N.A., Entrekin S.A. and Stephen M.L., 2010. A review of allochthonous organic matter dynamics and metabolism in streams. J. N. Am. Benthol. Soc., 29, 118-146.

Triska F.J., Kennedy V.C., Avanzino R.J., Zellweger G.W. and Bencala K.E., 1989. Retention and transport of nutrients in a third-order stream in northwestern California: hyporheic processes. Ecology, 70, 1893-1905.

Vannote R.L., Minshall G.W., Cummins K.W., Sedell J.R. and Cushing C.E., 1980. The river continuum concept. Can. J. Fish. Aquat. Sci., 37, 130-137.

Vervier P., Gibert J., Marmonier P. and Dole-Olivier M.-J., 1992. A perspective on the permeability of the surface freshwater-groundwater ecotone. J. N. Am. Benthol. Soc., $11,93-102$.
Wagner R., Schmidt H.H. and Marxsen J., 1993. The hyporheic habitat of the Breitenbach, spatial structure and physicochemical conditions as a basis for benthic life. Limnologica, 23, 285-294.

Webster J.R., 1975. Analysis of potassium and calcium dynamics in stream ecosystems on three southern Appalachian watersheds of contrasting vegetation, Ph.D. Dissertation, University of Georgia, Athens.

Webster J.R. and Benfield E.F., 1986. Vascular plant breakdown in freshwater ecosystems. Annu. Rev. Ecol. Syst., 17, 567-594.

Webster J.R. and Meyer J.L., 1997. Organic matter budgets for streams: a synthesis. J. N. Am. Benthol. Soc., 16, 141-161.

Webster J.R. and Patten B.C., 1979. Effects of watershed perturbation on stream potassium and calcium dynamics. Ecol. Monogr., 49, 51-72.

Webster J.R., Benfield E.F., Golladay S.W., Hill B.H., Hornick L.E., Kazmierczak R.F. and Perry W.E., 1987. Experimental studies of physical factors affecting seston transport in streams. Limnol. Oceanogr., 32, 848-863.

White D.S., 1993. Perspectives on defining and delineating hyporheic zones. J. N. Am. Benthol. Soc., 12, 61-69.

Williams D.D. and Hynes H.B.N., 1974. The occurrence of benthos deep in the substratum of a stream. Freshwater Biol., $4,233-256$ 